\title{
Resolving Civil Forfeiture Disputes
}

\author{
Rishi Batra*
}

\section{INTRODUCTION}

In February 2014, 24-year-old Charles Clarke was traveling through the Cincinnati/Northern Kentucky International Airport, returning to Florida after visiting relatives. ${ }^{1}$ He was carrying a large amount of cash$\$ 11,000$-, which he normally kept at home due to a lack of bank branches in his area, and which he had taken with him to Ohio because he did not want it getting lost in a family move. ${ }^{2}$ The cash, he said, came "from financial aid, various jobs, gifts from family, and educational benefits based on his mother's status as a disabled veteran." As he was about to board the plane, members of a Drug Enforcement Administration (DEA) Task Force seized the money. ${ }^{4}$ While Clarke did not have anything illegal in his possession, "the task force officers reasoned that the cash was the proceeds of drug trafficking, because Clarke was traveling on a recentlypurchased one-way ticket, he was unable to provide documentation of where the money came from, and they claimed his checked baggage had an odor of marijuana." 5 Despite not having proved he was guilty or even

* Associate Professor of Law, Texas Tech University School of Law; J.D., Harvard Law School; B.A., B.S., The University of California, Berkeley. The Author would like to thank Texas Tech University School of Law for its generous support of this Article. He would also like to thank Becky Jaffe, Professor Erin Archerd, Professor Lauren Newell, Professor Michael Moffitt, Professor Nancy Welsh, and the participants in the Marquette AALS ADR Works in Progress Conference for their thoughts, support, ideas, or comments.

1. Christopher Ingraham, Drug Cops Took a College Kid's Savings and Now 13 Police Departments Want a Cut, WASH. POST: WONKBLOG (June 30, 2015), https://www.washingtonpost.com/news/wonk/wp/2015/06/30/drug-cops-took-a-college-kids-lifesavings-and-now-13-police-departments-want-a-cut/?utm_term=.b1eccf584430; INST. FOR JUST., Ordinary Americans Are Victims of Policing for Profit in Our Nation's Airports, http://ij.org/case/kentucky-civil-forfeiture/ (last visited Dec. 12, 2017) [hereinafter Victims of Policing].

2. Victims of Policing, supra note 1.

3. Dick M. CARPENTER II ET AL., InSt. For Just., Policing For Profit: The AbuSE OF CiviL ASSET FORFEITURE 8 (2d ed. 2015), http://ij.org/wp-content/uploads/2015/11/policing-for-profit-2ndedition.pdf.

4. Ingraham, supra note 1.

5. Id. Clarke was a marijuana smoker, but the officer did not find any drugs or any other illegal items on Clarke or in his luggage. Id. 
suspected of a crime, law enforcement officers were able to keep his money. ${ }^{6}$

In April 2015, Joseph Rivers was traveling on an Amtrak train from Dearborn, Michigan, to Los Angeles, California, to make a music video. ${ }^{7}$ Rivers had \$16,000 in cash with him, which he said came from savings as well as money donated from his mother and other relatives. ${ }^{8}$ He carried the money in cash because he "had problems in the past with taking out large sums of money from out-of-state banks." In Albuquerque, a DEA agent boarded the train and began "asking various passengers, including Rivers, where they were going and why. When Rivers replied that he was headed to [Los Angeles] to make a music video, the agent asked to search his bags. Rivers complied." 10 In one of Rivers' bags, the DEA agent found the sum of cash, which was still in a bank envelope. ${ }^{11}$ Yet, the agent did not believe Rivers' claims about why he had the cash, nor did they believe his mother when they called her in Michigan to corroborate the story. ${ }^{12}$ The agent said they thought the money was involved in drug activity, despite the fact that the agent found no guns, drugs, or other material in Rivers's belongings that indicated that he was involved in drug trading. ${ }^{13}$ Ultimately, the agent did not arrest him or charge him with a crime, "but the DEA agent took his cash anyway - every last cent." ${ }^{\text {"14 }}$

Matt Lee of Clare, Michigan, was pulled over in 2011 on Interstate 80 in Humboldt County, Nevada. ${ }^{15}$ Lee was traveling from his parents' home in Nevada to California, where he was had been promised work. ${ }^{16}$ He was

6. Id. Clarke was charged for conduct unrelated to the cash he was carrying or any drug charges. $I d$. Clarke was charged with resisting arrest and assaulting an officer for allegedly "yelling" and "struggling" with officers during the incident. $I d$. The charges were subsequently dropped, although law enforcement kept the cash. Id.

7. Joline Gutierrez Krueger, DEA to Traveler: Thanks, I'll Take that Cash, ALBUQUERQUE J. (May 6, 2015, 12:05 AM), https://www.abqjournal.com/580107/dea-agents-seize-16000-fromaspiring-music-video-producer.html.

8. Id.

9. Id.

10. $I d$.

11. $I d$.

12. Id.

13. Christopher Ingraham, How the DEA took a Young Man's Life Savings Without Ever Charging Him With a Crime, WASH. POST: WONKBlOG (May 11, 2015) https://www.washingtonpost.com/news/wonk/wp/2015/05/11/how-the-dea-took-a-young-mans-lifesavings-without-ever-charging-him-of-a-crime/?utm_term $=.2 \mathrm{c} 10 \mathrm{c} 9 \mathrm{~b} 34 \mathrm{f} 0 \mathrm{~d}$.

14. $I d$.

15. Robert O'Harrow Jr. et al., They Fought the Law. Who Won?, WASH. Post (Sept. 8, 2014), $\mathrm{http} / / / \mathrm{www} . w a s h i n g t o n p o s t . c o m / s f / i n v e s t i g a t i v e / 2014 / 09 / 08 /$ they-fought-the-law-who-won.

16. Id. 
carrying \$2,500 in cash, loaned from his father. ${ }^{17}$ When Lee was pulled over by a Humboldt County Sheriff's Deputy, the deputy

asked whether Lee was carrying any currency and summoned a K-9 officer. Dove told Lee ... to get out of the car and stand at the edge of the desert, while a dog sniffed for drugs. The deputy told Lee that he didn't believe his story that he was moving to California, because he was carrying so little baggage, Lee told The [Washington] Post. Lee has no criminal record. When a search turned up Lee's remaining $\$ 2,400$ in cash, Dove and his colleague exchanged high-fives, Lee said. Dove said he was taking the money under state law because he was convinced that Lee was involved in a drug run. Lee was left with only the $\$ 151$ in his pocket. ${ }^{18}$

He eventually "hired a Reno attorney to get his money back and Humboldt County agreed to return it. But the attorney took about half as his fee and costs, $\$ 1,269.44$, leaving Lee with only $\$ 1,130.56 . " 19$

Unfortunately, cases like these are not rare. Under a legal process known as civil asset forfeiture, state and federal laws allow law enforcement officials and the government to seize assets from individuals who are not charged with a crime if the property is suspected of being involved in criminal activity. ${ }^{20}$ This is true even if the owner of the property is not charged with the underlying crime. ${ }^{21}$ Indeed, in 2014, The Washington Post analyzed 400 cases in seventeen states that were examples of civil forfeiture during traffic stops. ${ }^{22}$ Police stopped motorists under the pretext of a minor traffic infraction, analyzed the intentions of motorists by assessing nervousness, and requested permission to search the vehicle without a warrant. ${ }^{23}$ In most cases, officers did not even make an arrest. $^{24}$

However, that same study found that between September 11, 2001 and September 2014, the Department of Justice's (DOJ's) equitable sharing program, which allows local law enforcement to share in the proceeds of

\footnotetext{
17. Id.

18. $I d$.

19. Id.

20. See, e.g., 18 U.S.C. $\S 981$ (2012) (federal general civil forfeiture statute); 21 U.S.C. $\S 881$ (2012) (federal drug trafficking civil forfeiture statute).

21. See, e.g., United States v. 3120 Banneker Drive, 691 F. Supp. 497, 499 (D.D.C. 1988) (stating that "property is subject to civil forfeiture even if its owner is acquitted of —or never called to defend against-criminal charges").

22. O'Harrow Jr. et al., They Fought the Law, supra note 15.

23. $I d$.

24. $I d$.
} 
property seized through civil forfeiture, ${ }^{25}$ "was responsible for nearly 62,000 seizures of cash without warrants or criminal indictments filed against the owners. Of the $\$ 2.5$ billion forfeited as a result, state and local agencies received $\$ 1.7$ billion and federal agencies received $\$ 800$ million."26

These numbers are only likely to grow in the coming years. Attorney General Jeff Sessions has expressed support for the practice, calling it "appropriate" as a tool for law enforcement, ${ }^{27}$ and "one of law enforcement's most effective tools to reduce crime." 28 The Attorney General recently issued an $\operatorname{order}^{29}$ authorizing forfeiture "whenever the conduct giving rise to the seizure is in violation of federal law." 30

This order is sweeping in its scope. Civil asset forfeiture is available to the federal government for the proceeds of more than 200 state and federal crimes ${ }^{31}$ under the broad authority of 18 U.S.C. $\S 981$, which provides for forfeiture in cases of money laundering, counterfeiting, embezzlement, motor vehicle offenses, terrorism, and many other crimes. $^{32}$ These 200 crimes are either enumerated in the text or incorporated by reference from the federal money laundering statutes. ${ }^{33}$ Many other state and federal statutes also authorize civil forfeiture,

25. See infra notes $122-26$ and accompanying text discussing the DOJ's equitable sharing program; see also U.S. DEP'T JUST., Equitable Sharing Program, https://www.justice.gov/criminalmlars/equitable-sharing-program (last updated Oct. 18, 2017) [hereinafter Equitable Sharing Program].

26. CARPENTER II ET AL., supra note 3, at 29 (footnote omitted) (citing O'Harrow Jr. et al., supra note 15$)$.

27. U.S. DEP'T JuST., Attorney General Jeff Sessions Delivers Remarks to the National District Attorneys Association (July 17, 2017), https://www.justice.gov/opa/speech/attorney-general-jeffsessions-delivers-remarks-national-district-attorneys-association.

28. OfFice OF AtT'y Gen., Order No. 3946-2017, Federal Forfeiture OF Property SEIZEd By STATE AND Local Law ENForCEMENT AgenCies (July 19, 2017), https://www.justice.gov/ file/982611/download.

29. $I d$.

30. Id. This supersedes several orders limiting the practice of civil asset forfeiture under previous attorney generals. U.S. DeP'T Just., POLICY DireCTIVE 17-1, POLICY GUIDANCE ON THE ATtORNEy GENERAL's ORDER ON FEDERAL ADOPTION AND ForfEITURE OF PROPERTY SEIZED BY StATE AND LOCAL LAW ENFORCEMENT AGENICES (2017), https://www.justice.gov/file/982616/ download.

31. Craig Gaumer, A Prosecutor's Secret Weapon: Federal Civil Forfeiture Law, U.S. ATTORNEYs' BuLl. Nov. 2007, at 59, 62, https://www.justice.gov/sites/default/files/usao/legacy/ 2007/12/21/usab5506.pdf.

32. 18 U.S.C. $\S 981(\mathrm{a})(1)(\mathrm{A})-(\mathrm{G})(2012)$

33. Id. $\S \S 1956(\mathrm{c})(7), 1961(1)(2012)$. One exception is for currency reporting offenses that violate Subchapter II of Chapter 53 of Title 31 of the United States Code - for which civil and criminal forfeiture is authorized under 31 U.S.C. $\$ 5317$ (c) (2012). See Stefan D. CASSELla, Asset FORFEITURE LAW IN THE UNITED STATES $§ 27-2$, at 961 (2d ed. 2013) [hereinafter CASSELLA, ASSET FORFEITURE LAW IN THE U.S.]. 
including, importantly, 21 U.S.C. $§ 881$, which specifically authorizes forfeiture for drug trafficking. ${ }^{34}$

In addition, asset forfeiture is available for almost any type of property that may be involved in criminal activity, including real property, automobiles, firearms, and, of course, cash. ${ }^{35}$ This Article focuses on a particularly difficult type of dispute to resolve, as in the examples above, of civil forfeiture of cash assets. This type of dispute can arise fairly frequently in the world of civil forfeiture disputes, sometimes due to seizures based on federal structuring law, ${ }^{36}$ under which the government can seize assets that it suspects are being deposited in bank accounts strategically to avoid reporting requirements. ${ }^{37}$ Cash forfeiture can arise in other cases as well, as illustrated above with traffic stops leading to forfeiture of cash assets suspected, legitimately or not, of being involved in narcotics investigations. ${ }^{38}$

As this Article will show, civil forfeiture disputes regarding cash are some of the most difficult to resolve due to the psychological and structural nature of these disputes. However, as these disputes arise fairly frequently, tools are needed for judges and the judicial system as a whole to resolve them. While legislative action could help resolve these disputes by changing the legal framework within which they occur, until that time, judges are tasked with resolving civil forfeiture actions. By focusing on the nature of these disputes, and analyzing the judicial role in encouraging settlement, this Article proceeds in four parts.

Part II of this Article describes the issue of civil forfeiture, and the legal mechanisms that allow the government to seize control of assets without a criminal conviction. It also describes the legal mechanisms that individuals who have had their assets seized can use to try to recover these assets, and shows how these recoveries are treated as civil, rather than criminal, matters that proceed against the property itself rather than the individual.

Part III discusses the nature of these civil forfeiture disputes from a dispute resolution perspective and explores why these suits are unlikely to settle despite being civil matters. In particular, this Part describes the barriers to resolution that these conflicts have to overcome, including both structural barriers as well as psychological barriers that impact both the government and the defendants.

\footnotetext{
34. 21 U.S.C. $\S 881$ (2012).

35. 18 U.S.C. $\$ 981(\mathrm{a})(1)(\mathrm{A})-(\mathrm{G})$.

36. See Timothy J. Ford, Note, Due Process for Cash Civil Forfeitures in Structuring Cases, 114 MiCH. L. REV. 455, 456 (2015).

37. 31 U.S.C. $\$ 5324$ (2012).

38. See O’Harrow Jr. et al., They Fought the Law, supra note 15.
} 
Part IV looks to modern trends in judging to see how judges can and should respond to conflicts such as civil forfeiture that are unlikely to settle on their own. The managerial style of judging is now ascendant both in the civil and criminal contexts. Under the managerial style of judging, the management of cases is more important than any particular trial, and judges attempt to involve themselves in cases in order to promote settlement. Under this conception of the judicial role, judges can take an active role in encouraging settlement of civil forfeiture disputes.

Part V uses the lens of dispute resolution to guide judges using this managerial role to help settle civil forfeiture disputes. It encourages judges to analyze the structure of these disputes to better understand how to manage these cases appropriately. This Part suggests that judges can encourage settlement by changing the parties' alternatives, changing the bargaining zone, and removing the zero sum nature of the disputes through procedural mechanisms.

The Article then ends with a brief conclusion that suggests areas for further improvement of these disputes.

\section{UNDERSTANDING CIVIL FORFEITURE DISPUTES}

Civil forfeiture actions have a long legal history in the United States, although their use has increased significantly given two somewhat recent reforms. This Part lays out the legal basis for civil forfeiture actions as well as discusses the justifications and, importantly, the criticisms of the procedure.

\section{A. The Legal Basis for Civil Asset Forfeiture}

The origins of forfeiture laws in the United States can be traced back to seventeenth century English maritime law, which allowed violations to be punished by seizure and forfeiture of ships and cargo. ${ }^{39}$ Borrowing from these laws, the first Congress created the initial federal forfeiture statutes in 1789 to authorize the forfeiture of ships and cargo involved in customs violations. ${ }^{40}$ Eventually these statutes were expanded to cover vessels involved in piracy and the slave trade. ${ }^{41}$ In the nineteenth century,

39. Donald J. Boudreaux \& A.C. Pritchard, Civil Forfeiture and the War on Drugs: Lessons from Economics and History, 33 SAN DIEGO L. REV. 79, 93-96 (1996).

40. Cassella, Asset Forfeiture in the U.S., supra note 33, § 2-2 at 29 (citing Austin v. United States, 509 U.S. 602, 611-14 (1993)).

41. Id. (citing United States v. Bajakajian, 524 U.S. 321, 340-41(1998)). 
Congress expanded the forfeiture power during the Civil War ${ }^{42}$ and, in the twentieth century, expanded the power during prohibition to reach property involved with crimes involving taxes on alcohol and distilled spirits, counterfeiting, gambling, drug trafficking, and smuggling. ${ }^{43}$

The government's forfeiture authority, and the number of civil forfeiture cases brought, increased dramatically due to two more recent law changes. In 1978 Congress rewrote federal drug forfeiture laws to authorize the government to forfeit proceeds of drug crimes. ${ }^{44}$ Then again in 1984, civil forfeiture law changed significantly when Congress gave the government the ability to forfeit property used to facilitate drug crimes (rather than just the proceeds) as part of amendments to the Comprehensive Drug Abuse Prevention and Control Act. ${ }^{45}$ Instead of forfeiting only property used to commit violations, the government now had the ability to take "any property that made the crime easier to commit or harder to detect." 46 In addition, these amendments created the DOJ's Assets Forfeiture Fund for depositing forfeiture proceeds for federal agency use. ${ }^{47}$ Lawmakers in several states have followed the federal model and amended their states' civil forfeiture laws to fund local and state agencies with seized forfeiture assets. ${ }^{48}$

The Civil Asset Forfeiture Reform Act of 2000 (CAFRA) somewhat curtailed the power of these amended federal civil forfeiture laws. ${ }^{49}$ The CAFRA reforms added increased protections for property owners, including time limits for the government to provide notice and file forfeiture actions, a defense for innocent owners, and hardship exemptions. ${ }^{50}$ CAFRA also "required the government, not the claimant, to prove the property is connected to a crime, eliminated the requirement that claimants post a bond before being able to contest a civil forfeiture in court, and provided representation for indigent claimants under limited

\footnotetext{
42. Boudreaux \& Pritchard, supra note 39 , at 98-99.

43. CASSELla, ASSET ForfeituRE IN THE U.S., supra note 33, § 2-4 at 33.

44. Id.; 21 U.S.C. $\$ 881(\mathrm{a})(6)(2012)$.

45. Cassella, Asset Forfeiture in the U.S., supra note 33, § 2-4 at 33; 21 U.S.C. § 881(a)(7); Comprehensive Crime Control Act of 1984, Pub. L. No. 98-473, 98 Stat. 1837, 1976 (1984).

46. Stefan D. Cassella, An Overview of Asset Forfeiture in the United States, in CIVIL Forfeiture of CRiminal Property: Legal MeAsures For TARgeting the ProceEds OF CRIME 23, 27-28 (Simon N.M. Young ed., 2009) [hereinafter Cassella, Overview of Asset Forfeiture] (citing United States v. Shifferli, 895 F. 2d. 987, 990 (4th Cir. 1990)).

47. Comprehensive Crime Control Act of 1984, Pub. L. No. 98-473, § 310, 98 Stat. 1976, 2052 (1984) (codified as amended 28 U.S.C. 524(c)).

48. CARPENTER II ET AL., supra note 3, at 10.

49. Civil Asset Forfeiture Reform Act of 2000, Pub. L. No. 106-185, 114 Stat. 202 (2000) (codified at 18 U.S.C. $\S \S 983,985$ and 28 U.S.C. $\S \S 2465-67$ ).

50. Ford, supra note 36, at 461.
} 
circumstances." ${ }^{51}$ Despite these reforms, critics of civil forfeiture claim that still not enough is done to protect property owners. ${ }^{52}$

While there is "no single all-encompassing federal forfeiture statute[,]" ${ }^{\prime 53}$ there are a number of statutes that authorize civil forfeiture for a broad range of property involved in a broad range of criminal activity. ${ }^{54}$ The federal civil drug forfeiture statute authorizes forfeiture of

[a]11 moneys, negotiable instruments, securities, or other things of value furnished or intended to be furnished by any person in exchange for a controlled substance or listed chemical in violation of [Subchapter I of Chapter 13 of Title 21], all proceeds traceable to such an exchange, and all moneys, negotiable instruments, and securities, used or intended to be used to facilitate any [such] violation[, $]^{55}$

along with ten other classes of property. ${ }^{56}$ This gives broad civil forfeiture authority for proceeds of all Title 21 crimes and felony violations thereof. ${ }^{57}$

The other commonly used civil forfeiture statute is 18 U.S.C. $\S 981$, which also provides a broad swath of forfeiture authority. ${ }^{58}$ Pursuant to $\S 981$ (a), there are over 200 state and federal crimes ${ }^{59}$ that subject property involved to civil forfeiture, including providing for forfeiture in cases of money laundering, counterfeiting, embezzlement, motor vehicle offenses, terrorism, and many other crimes. ${ }^{60}$ These 200 crimes are either enumerated in the text of $\S 981$ (a), or incorporated by reference from the federal money laundering statutes. ${ }^{61}$ Many federal statutes also authorize civil forfeiture, and many other state statutes do as well. ${ }^{62}$

51. CARPENTER II ET AL., supra note 3, at 168 n.11.

52. See David Pimentel, Forfeitures Revisited: Bringing Principle to Practice in Federal Court, 13 NEV. L.J. 1, 23-32 (2012) (surveying criticisms of CAFRA).

53. Gaumer, supra note 31 , at 60 .

54. Id.

55. 21 U.S.C. $\$ 881(a)(6)(2012)$.

56. See id. $\S 881(\mathrm{a})$; see also Gaumer, supra note 31 , at 60-61.

57. This covers violations of Subchapter I of Chapter 13, 21 U.S.C. $\$ \S 801-904$, and violations of Subchapter II of Chapter 13, 21 U.S.C. $\$ \S 951-971$.

58. Graumer, supra note 31 , at 61.

59. Id. at 62 .

60. 18 U.S.C. $\S 981(a)(1)(A)-(G)(2012)$.

61. Id. § 1956(c)(7) (2012); see also Racketeer Influenced and Corrupt Organization (RICO), Pub. L. No. 91-452, § 901(a), 84 Stat. 922, 941 (codified as amended at 18 U.S.C. $\S \S 1961-1968$ ). One exception is for currency reporting offenses that violate Subchapter II of Chapter 53 of Title 31 of the United States Code-for which civil and criminal forfeiture is authorized under 31 U.S.C. $\S$ 5317(c) (2012). CASSElla, ASSET FORFEITURE LAW IN THE U.S., supra note 33, § 27-2 at 961.

62. Gaumer, supra note 31 , at 62 . 


\section{B. The Nature of Civil Forfeiture Actions}

In a civil forfeiture case, the government files a civil action in rem against the property itself and must prove, by a preponderance of the evidence, that the property was derived from or was used to commit a crime. Because a civil forfeiture does not depend on a criminal conviction and is an in rem action against the property itself, the forfeiture action may be filed without a criminal indictment. ${ }^{63}$

One amusing result of the fact that the proceedings are in rem-i.e. against the property itself-is the rise of peculiar case names, ${ }^{64}$ such as United States v. Ninety-Three (93) Firearms, ${ }^{65}$ United States v. One 1992 Ford Mustang GT, ${ }^{66}$ United States v. \$557,933.89, More or Less, in U.S. Funds, ${ }^{67}$ and United States v. Approximately 64,695 Pounds of Shark Fins. ${ }^{68}$ However, while this may seem to imply that the property itself is guilty of a crime, ${ }^{69}$ courts justified this legal fiction as a procedural convenience to give anyone with an interest in the property to come forward at once rather than having "a separate civil action against every person or entity with a potential legal interest in the property."

Because civil forfeiture proceeds against the property in rem, there is no need for a criminal conviction to accompany the civil proceedings. Therefore, many of the usual criminal law protections do not apply. For example, pursuing both a civil and criminal forfeiture based on the same

63. See Jeffrey Simser, Perspectives on Civil Forfeiture, in CIVIL ForfeIture OF CRIMINAL Property: Legal Measures for Targeting the Proceeds of Crime 13, 15 (Simon N.M. Young ed., 2009). See United States v. Cherry, 330 F.3d 658, 668 n.16 (4th Cir. 2003) ("The most notable distinction between civil and criminal forfeiture is that civil forfeiture proceedings are brought against property, not against the property owner; the owner's culpability is irrelevant in deciding whether property should be forfeited."); United States v. One-Sixth Share of James J. Bulger in All Present and Future Proceeds of Mass Millions Lottery Ticket No. M246233, 326 F.3d 36, 40 (1st Cir. 2003) ("Because civil forfeiture is an in rem proceeding, the property subject to forfeiture is the defendant. Thus, defenses against the forfeiture can be brought only by third parties, who must intervene."); United States v. \$734,578.82 in U.S. Currency, 286 F.3d 641, 657 (3d Cir. 2002) ("[Civil] forfeiture is not conditioned upon the culpability of the owner of the defendant property.").

64. Stefan D. Cassella, Overview of Asset Forfeiture Law in the United States, U.S. ATTORNEYs' Bull. Nov. 2007, at 15 [hereinafter Cassella, U.S. ATTORNEYS' BULLETIN], https://www.justice.gov/ sites/default/files/usao/legacy/2007/12/21/usab5506.pdf.

65. 330 F.3d 414 (6th Cir. 2003).

66. 73 F. Supp. 2d 1131 (C.D. Cal. 1999).

67. 287 F.3d 66 (2d Cir. 2002).

68. 520 F.3d 976 (9th Cir. 2008).

69. See LastWeekTonight, Last Week Tonight with John Oliver (HBO): Civil Forfeiture, YOUTUBE (Oct. 5, 2014), https://youtu.be/3kEpZWGgJks (including a skit in which a house is put under arrest).

70. Cassella, U.S. AtTORNEYS' Bulletin, supra note 64, at 16 (citing United States v. Ursery, 518 U.S. 267, 297 (1996) (Kennedy, J., concurring)). 
underlying offense is not a violation of the Fifth Amendment Double Jeopardy Clause. ${ }^{71}$ Even an acquittal on the criminal claim does not bar a civil forfeiture action by the government. ${ }^{72}$ Similarly, an overturned criminal conviction has no effect on the civil forfeiture action. ${ }^{73}$

Procedurally, civil forfeiture actions are similar to other civil cases. ${ }^{74}$ 18 U.S.C. $\S 983$ and Supplemental Rule G of the Federal Rules of Civil Procedure govern civil forfeiture procedure. ${ }^{75}$

First, the government plaintiff files a verified forfeiture complaint alleging that, pursuant to one of the many forfeiture statutes, the relevant property is subject to civil forfeiture. ${ }^{76}$ Claimants to the property must then answer the complaint and file their property claims within the period prescribed by statute. ${ }^{77}$

The case moves through the regular process of civil discovery, motion practice, and trial. ${ }^{78}$ Claimants may request a jury trial to establish they were the innocent owner, as guaranteed by the Seventh Amendment. ${ }^{79}$ The government must establish by a preponderance of evidence that the property is subject to forfeiture by a preponderance of the evidence standard. ${ }^{80}$

If the government establishes a connection between the property and a criminal offense, a person can still contest the forfeiture by proving the elements of the innocent owner defense. ${ }^{81}$ To protect the interests of those

71. Ursery, 518 U.S. at 270-71.

72. United States v. One Assortment of 89 Firearms, 465 U.S. 354, 366 (1984) (holding that an acquittal of a firearms violation under 18 U.S.C. $\S 922$ does not bar civil forfeiture under $\S 982(\mathrm{~d})$ ); One Lot Emerald Cut Stones and One Ring v. United States, 409 U.S. 232, 237 (1972) (per curiam) (holding that acquittal on a smuggling charge does not bar a later civil forfeiture action); United States v. 1988 Oldsmobile Cutlass Supreme 2 Door, 983 F.2d 670, 675 (5th Cir. 1993) (holding that acquittal of a claimant does not create material issue of fact as to avoid summary judgment in civil forfeiture case).

73. Cassella, U.S. Attorneys' Bulletin, supra note 64, at 16 (citing United States v. One "Piper" Aztec "f” De Luxe Model 250 Pa 23 Aircraft Bearing Serial No. 27-7654057, 321 F.3d 355, 360-61 (3d Cir. 2003)).

74. Cassella, U.S. ATtORnEYS' Bulletin, supra note 64, at 16.

75. $I d$.

76. Id.

77. Id. If no one responds to the initial notice of forfeiture, "the agency concludes the matter by entering a declaration of forfeiture that has the same force and effect as a judicial order." Cassella, Overview of Asset Forfeiture, supra note 46, at 38; see 18 U.S.C. § 983(a)(1)-(2) (2012).

78. Cassella, U.S. ATtORnEYS' Bulletin, supra note 64, at 16.

79. Id.; see United States v. Bearden, 328 F.3d 1011, 1014 n.2 (8th Cir. 2003) (holding that the claimant has a Seventh Amendment right to a jury trial on her innocent owner defense).

80. Cassella, U.S. AtTORnEys' Bulletin, supra note 64, at 16; see One "Piper" Aztec, 321 F.3d at 357 .

81. CASSElla, Asset Forfeiture IN THE U.S., supra note 33, § 1-4, at 16; Stefan D. Cassella, The Uniform Innocent Owner Defense to Civil Asset Forfeiture: The Civil Asset Forfeiture Reform Act 
innocent property owners either unaware that their property was being used for illegal purposes, or those owners who took reasonable steps to stop the use, Congress enacted a "uniform innocent owner defense." 82 Under the statute, a person contesting forfeiture must establish both ownership interests and innocence by a preponderance of the evidence. ${ }^{83}$ This statute has been criticized as removing the presumption of innocence and shifting the burden of proving a negative onto the innocent owner. ${ }^{84}$

\section{Justifications for Civil Asset Forfeiture}

Justifications for civil asset forfeiture are fourfold. ${ }^{85}$ First, law enforcement justifies civil forfeiture as a means to both punish wrongdoers and prevent the tools of the crime from being used again by removing them from circulation. ${ }^{86}$ This is particularly true of the instrumentalities of crime, such as guns or cars with compartments used to conceal drugs, but can also be justified to remove property where drugs are sold (i.e. a "crack house") or businesses used to commit criminal activity, such as insurance fraud. ${ }^{87}$

Asset forfeiture is also justified as an effective way to recover property that may be used to compensate innocent victims, such as in cases involving property offenses and fraud. ${ }^{88}$ Forfeiture accomplishes this goal by preserving this property pending trial, so that the property is available after the case has settled. ${ }^{89}$

Forfeiture of assets is also a way to reduce incentives for crime by reducing the profit motive. ${ }^{90}$ Asset forfeiture reduces the incentive of an individual criminal from engaging in economic crime, while also avoiding the impression that criminal enterprise is worth the risk, especially

of 2000 Creates a Uniform Innocent Owner Defense to Most Civil Forfeiture Cases Filed by the Federal Government, 89 KY. L.J. 653, 654-55 (2001) [hereinafter Cassella, Uniform Innoncent Owner Defense].

82. Cassella, U.S. AtTORneYs' Bulletin, supra note 64, at 16 (citing 18 U.S.C. § 983(d) (2012)).

83. Cassella, Uniform Innoncent Owner Defense, supra note 80, at 671-72.

84. CARPENTER II ET AL., supra note 3, at 20.

85. See Kaley v. United States, 134 S. Ct. 1090, 1094 (2014) (noting that forfeitures help "punish wrongdoing, deter future illegality, and 'lessen the economic power' of criminal enterprises" and are also used to "recompense victims of crime").

86. Cassella, U.S. ATTORNEYs' BULLETIN, supra note 64, at 8.

87. $I d$.

88. See 18 U.S.C. $\S 981(e)(6)$ (2012) (authorizing the government to use property forfeited in civil forfeiture cases to pay restitution to victims of underlying crimes); 21 U.S.C. § 853(i) (2012) (treating criminal forfeiture in the same fashion).

89. Cassella, U.S. AtTORNEYs' Bulletin, supra note 64 , at 8.

90. Id. 
compared to a regime where criminals would be allowed to keep the profits of their criminal enterprise. ${ }^{91}$ The message is also sent to "lawabiding citizens" that crime does not pay, by stripping the criminal of the "trappings" of an expensive and often "enviable lifestyle." 92 Seeing the loss of expensive goods and property enjoyed by the criminal sends a signal that the benefits of a criminal enterprise are "illusory" or "temporary." 93 Finally, asset forfeiture also functions as a method of punishment. ${ }^{94}$ Giving a criminal his "just [deserts]" is an important punishment motive for asset forfeiture. ${ }^{95}$

\section{Criticisms of Civil Forfeiture}

As a result of increased media scrutiny from the likes of The New Yorker, ${ }^{96}$ The Washington Post ${ }^{97}$ and even comedian John Oliver, ${ }^{98}$ several executive branch agencies have changed their policies regarding civil forfeiture. However, several criticisms remain.

\section{Profit Incentives for Law Enforcement Officers}

One of the major criticisms of the current civil asset forfeiture laws in the United States is the incentives that are created for law enforcement to pursue civil forfeiture. ${ }^{99}$ Funds and property seized through civil asset forfeiture are deposited in the DOJ's Assets Forfeiture Fund. ${ }^{100}$ In 1986, the year after the fund was established, it took in $\$ 93.7$ million in deposits,

91. Id; see also United States v. Bajakajian, 524 U.S. 321, 328, 343-44 (1998) (civil forfeiture is both a fine and a punishment).

92. Cassella, U.S. ATtORneys' Bulletin, supra note 64, at 8; see also OFFICE OF THE U.S. ATTORNEYS, U.S. ATTORNEYS' MANUAL § 9-118.010 (updated July 2017) (“The Department of Justice asset forfeiture program has three primary goals: (1) to . . deter criminal activity by depriving criminals of property used or acquired through illegal activities . ...").

93. Simon N.M. Young, Introduction, in CiviL ForfeITURE OF CRIMINAL Property: LEGAL Measures for Targeting the Proceeds of Crime 1, 8-9 (Simon N.M. Young ed., 2009).

94. Id. at 9 .

95. Id;see also Austin v. United States, 509 U.S. 602, 619-23 (1993) (civil forfeiture as punishment).

96. Sarah Stillman, Taken, NEw YORKER (Aug. 12 \& 19, 2013), https://www.newyorker.com/magazine/2013/08/12/taken.

97. Michael Sallah et al., Stop and Seize: Aggressive Police Take Hundreds of Millions of Dollars from Motorists not Charged with Crimes, WASH. PosT (Sept. 6, 2014), http://www.washingtonpost.com/sf/investigative/2014/09/06/stop-andseize/?utm term=.66a8aade0e23.

98. Last Week Tonight with John Oliver, supra note 69.

99. See CARPENTER II ET AL., supra note 3, at 43.

100. Id. at 10 . 
but in 2014 that number had increased to $\$ 4.5$ billion. ${ }^{101}$ Net assets, the amount retained in the fund, topped $\$ 1$ billion in 2007 and increased to $\$ 4.5$ billion in $2014 .{ }^{102}$ State data is more difficult to come by because of the lack of reporting requirements, but for states where data is available, there is a similar rate of growth, with Texas seizing \$46 million in 2012, followed by Arizona at $\$ 43$ million. ${ }^{103}$ Money seized through forfeiture is a large source of revenue for these federal and state agencies, and critics argue this gives these agencies a large incentive to "police for profit." 104

In addition, local law enforcement agencies that coordinate enforcement operations with the federal government, such as in narcotics investigations, can share in the funds seized through what is known as the "Equitable Sharing Program."105 Through this program, federally forfeited property can be shared with participating state and local law enforcement agencies. ${ }^{106}$ The state and local agencies can participate in joint investigations with federal agencies, either through participation in federal task forces, joint task forces, or local investigations that develop in to federal cases. ${ }^{107}$ Alternatively, state and local agencies can share in federal sharing even after the funds are seized, through what is known as "adoption." 108 A federal agency can choose to "adopt" property turned over to it "where the conduct giving rise to the seizure is in violation of federal law and where federal law provides for forfeiture."109

The incentives for law enforcement to participate in equitable sharing are significant. Under the Equitable Sharing Program, up to $80 \%$ of seized assets can be returned to law enforcement to pay for law enforcement budgetary activities. ${ }^{110}$ While the Justice Department has recently reformed the recommendations for what can be paid for with seized assets, the list is still very broad and exceptions remain. ${ }^{111}$ In the past, seized

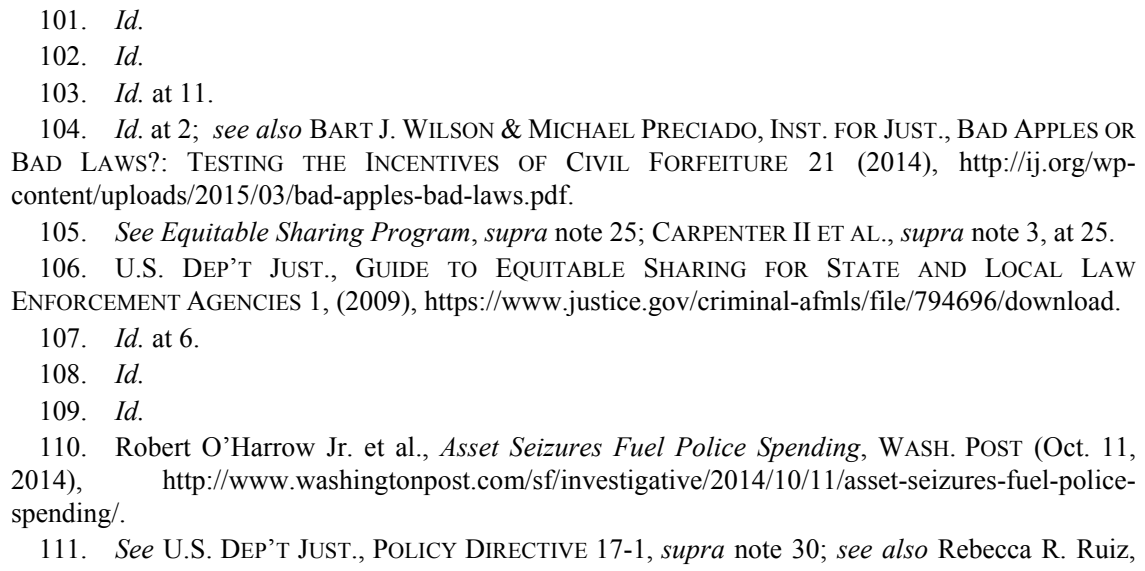

111. See U.S. DeP'T JUST., POLICY DiRECTIVE 17-1, supra note 30; see also Rebecca R. Ruiz, 
assets have been used to pay for a wide variety of legitimate and not so legitimate expenses. One of The Washington Post's investigations found that seized funds were used not only to pay for guns, armored cars, and electronic surveillance, but also luxury vehicles, travel, and a clown named Sparkles. ${ }^{112}$ There is virtually no check on what seized funds can be spent on, and thus, in addition to funding for the district attorney general, equipment, training and salaries for personnel, funds have been used for popcorn machines, catering, baseball leagues, and directly to law enforcement officers themselves. ${ }^{113}$ Equitable sharing is used as a routine source of funding at every level ${ }^{114}$ and has been extremely profitable for law enforcement agencies.

This "policing for profit" motive, critics suggest, impacts the way that policing is done. ${ }^{115}$ As part of a multi-year investigation, a television news team in Tennessee found that more than ten times as many stops were made on the side of the highway coming back from the East Coast, presumably after drug sales were made, than on the side headed to the East Coast, which may also contain drugs. ${ }^{116}$

\section{Difficulties in Challenging Civil Forfeiture}

Another criticism leveled against the civil forfeiture process is the difficulty that claimants face in challenging civil forfeiture actions. Critics point out that civil forfeiture proceedings can take a year or more to resolve ${ }^{117}$ and require the assistance of counsel. ${ }^{118}$ Because the action is a civil proceeding rather than a criminal one, property claimants have no right to counsel, and so must acquire counsel at their own cost. ${ }^{119}$ Without an attorney, claimants face a severe disadvantage, as deadlines for claims

\footnotetext{
Justice Dept. Revives Criticized Policy Allowing Assets to Be Seized, N.Y. Times (July 19, 2017), https://www.nytimes.com/2017/07/19/us/politics/justice-department-civil-asset-forfeiture.html? mcubz=1\&mtrref=undefined (discussing criticisms of the guidance); see U.S. DEP'T JUST., INTERIM Policy Guidance Regarding THe Use of Equitable Sharing Funds, https://www.justice.gov/ sites/default/files/criminal-afmls/legacy/2014/07/31/Use-of-Shared-Funds-Policy-2014.pdf.

112. O'Harrow Jr. et al., Asset Seizures Fuel Police Spending, supra note 110.

113. CARPENTER II ET AL., supra note 3, at 16.

114. See id.

115. See id. at $2-3$.

116. Id. at 16 .

117. Dick M. Carpenter II \& Larry Salzman, Inst. For Just., Seize First, Question LATER: THE IRS AND CIVIL FORFEITURE 4 (2015), http://ij.org/images/pdf_folder/private_property/ seize-first-question-later.pdf ("People whose money is seized likely face a long legal battle to win it back. The average forfeiture for suspected structuring took nearly a year to complete.").

118. CARPENTER II ET AL., supra note 3, at 12 .

119. Id.
} 
opposing civil forfeiture proceedings can be harsh, ${ }^{120}$ and trials can be potentially long and complicated. ${ }^{121}$ Filing a civil forfeiture action comes with additional risks, including increased attention from law enforcement leading to a criminal prosecution and exposure to civil discovery, including depositions. ${ }^{122}$ Indeed, several potential claimants who have had their property seized were threatened with criminal prosecution if they chose to object to the forfeiture. ${ }^{123}$

In addition, several states make it even more difficult to challenge civil forfeiture in court. In Illinois, for example, property owners must first pay a bond of $\$ 100$ or ten percent of the property's value, whichever is greater. ${ }^{124}$ If the owners challenge and lose, they must pay the full cost of the forfeiture proceedings, including the government legal costs, and give up the full value of the bond in addition to the property seized. ${ }^{125}$ Even if the claimants win, they lose ten percent of the value of the bond in addition to attorney costs. ${ }^{126}$

Overcoming these hurdles is frequently difficult for claimants, especially because the amount seized is often small enough that it may not be worth pursuing a claim. Data compiled by the libertarian-leaning Institute for Justice found that in ten states, the median property value forfeited ranged from $\$ 451$ in Minnesota to $\$ 2,048$ in Utah. ${ }^{127}$ Similarly, the more liberal American Civil Liberties Union of Pennsylvania found that between 2011 and 2013, half of all cash only forfeiture cases in Philadelphia involved less than $\$ 192 .{ }^{128}$ It is unsurprising, then, that forfeitures often go unchallenged by property owners. ${ }^{129}$

120. See Ford, supra note 36, at 461-64 (discussing CAFRA procedure for seizing property). For example, if no claim is timely filed within thirty days after notice, the IRS will sell seized property without declaring a forfeiture. I.R.C. § 7325(2) (2012).

121. Ford, supra note 36, at 459-60.

122. David B. Smith, 1-6 Prosecution and Defense of Forfeiture Cases $\S 6.02(3)(\mathrm{b})$ (Matthew Bender ed., 2017).

123. See, e.g., Stillman, supra note 96 . A couple was threatened with "felony charges for 'money laundering' and 'child endangerment"' resulting in a jail term, or given the option of signing over their cash to the city and returning to the road. $I d$. They were made to sign a waiver to this effect. $I d$.

124. 725 Ill. Comp. StAT. AnN. 150/6(C)-(D) (West 2008 \& Supp. 2014). There are exceptions for personal property worth more than $\$ 150,000$ and for real property. Id.

125. Id.

126. Id.

127. CARPENTER II ET AL., supra note 3, at 12. These numbers may not be representative as data is hard to acquire from other states. Id. at 169 n.29.

128. SCOtT Kelly, aClU of Pa., Guilty Property: How Law Enforcement TaKes \$1

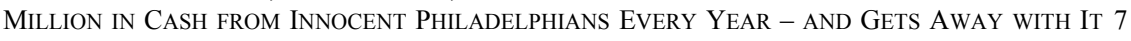
(2015), https://www.aclupa.org/files/3214/3326/0426/Guilty_Property_Report_-_FINAL.pdf.

129. CARPENTER II ET AL., supra note 3, at 12. 


\section{Low Standards of Proof}

Another concern of critics of civil forfeiture is the low standard of proof that is needed to seize assets. ${ }^{130}$ For most federal and state laws regarding most types of property, all law enforcement officers need to seize property is "probable cause" that the assets are connected to a crime that allows civil forfeiture, such as narcotics sales or money laundering. ${ }^{131}$ The low burden of proof extends to the civil forfeiture action itself, in which prosecutors must only meet the preponderance of the evidence standard, rather than the beyond a reasonable doubt standard that is required in criminal cases. ${ }^{132}$ Importantly, this applies both to the proof that the crime was committed and to the proof that the property was derived from or was used to commit the crime. ${ }^{133}$

\section{BARRIERS TO SETTLEMENT OF CIVIL FORFEITURE DISPUTES}

\section{A. Alternatives to Settlement}

One major barrier to the settlement of any dispute is the existence of a positive incentive for one or more of the participants to not settle the dispute. Negotiators on both sides of a dispute should regularly evaluate the "bargaining chips" that are derived from "the outcome that the law will impose if no agreement is reached." 134 This outcome that can be achieved away from the negotiating table is frequently referred to in the negotiation literature as the negotiator's "best alternative to negotiated agreement" or BATNA for short. ${ }^{135}$ The BATNA determines the range of possible bargaining outcomes, as negotiators should measure whatever offer is on the table relative to whatever their BATNA. ${ }^{136}$ Presumably, if the offer "at the table" is worse than the alternatives "away from the table," this is an offer that should not be agreed to by the party contemplating it. ${ }^{137}$ Effectively, the parties' respective BATNAs set both the ceiling and floor 
for the negotiation, and the range of possible outcomes between them becomes what is known as the Zone of Possible Agreement (ZOPA). ${ }^{138}$

Parties will measure the difference between the offer and the BATNA in terms of their own interests, which are the underlying reasons that motivate the parties to come to an agreement, whether those be financial, emotional, or reputational. The total amount that all sides perceive the deal they arrive at to be better than their BATNA is the amount of the "value creation" in the negotiation. ${ }^{139}$

"What stands out to me is the nature of how pervasive and dependent police really are on civil-asset forfeiture - it's their bread and butter-and, therefore, how difficult it is to engage in systemic reform," Vanita Gupta, of the American Civil Liberties Union, said to The New Yorker. ${ }^{140}$ This quote suggests one of the reasons that in the case of civil forfeiture, the government would be unlikely to settle this dispute. As noted above, the government, and in particular law enforcement, has financial incentives to keep as much of the money as possible. Because civil forfeiture money makes up a large part of both certain prosecutor's offices' budgets, as well as the budgets of law enforcement agencies, the chance of keeping the money through legal challenge, even at the risk of losing some of the cases, seems like a strong BATNA for the government. It is interesting to consider the relatively weak BATNA of the claimant as well, who has incentives to "settle" the case, but by walking away, as many do. However, there may be other incentives keeping them from settling, such as equity and justice seeking.

\section{B. Equity and Justice Seeking}

In cases of civil forfeiture, settlement may be more difficult to come by than in a regular civil case due to the equity and justice seeking behavior, particularly of the owners of the property being seized. Many of these owners feel aggrieved because they perceive their treatment as unfair, and will refuse to settle cases in order to get back all they believe they are owed. For example, Mandrel Stuart had \$17,550 taken from him during a traffic stop for a minor infraction in 2012. ${ }^{141}$ The thirtyfive-year-old African American owner of a small barbecue restaurant in Staunton, Virginia rejected a settlement offer for half of the money and

\footnotetext{
138. Robert H. MNOOKIN ET AL., Beyond WinNing: Negotiating to CREate Value in DEALS AND DISPUTES 19 (2000).

139. Id. at 15. See also FISHER \& URY, supra note 135, at 100-01.

140. Stillman, supra note 96 .

141. O'Harrow Jr. et al., They Fought the Law, supra note 15.
} 
demanded a jury trial instead. ${ }^{142}$ As he stated, "I paid taxes on that money. I worked for that money, ... Why should I give them my money?" "143 This attitude, while understandable given the situation, certainly does not promote settlement. In these cases, the sense of equity and justice seeking may be so strong that the owner of the property will go to trial and risk losing all of their cash rather than settle for a portion of it.

Another motivation for the owners of seized cash may be to shine a light on the perceived misdeeds of the government representatives in this case. This was certainly the motivation of James Morrow, an African American worker at a Tyson plant in Pine Bluff, Arkansas, who was pulled over in August 2007 in Tenaha, Texas. ${ }^{144}$ Police pulled Morrow over for "driving too close to the white line" and took $\$ 3,900$ from him, which he had recently withdrawn to pay for dental work. ${ }^{145}$ Morrow had his car impounded and was taken to jail where he pleaded with authorities to call his bank to see proof of his recent cash withdrawal, but they declined. ${ }^{146}$ While Morrow was encouraged by authorities to avoid getting a lawyer, he did so anyway, with the motivation, as he told The New Yorker, "to shine a big ol' light on them.",147

Morrow was in fact so motivated he took time off work to come to Nagadoches, Texas from his home in Arkansas to meet with a lawyer and eventually become the lead plaintiff in a class action against law enforcement in Tenaha. ${ }^{148}$ He would eventually take off of work again for the trial, as would many of the other plaintiffs from around the country who were impacted by highway interdiction in Tenaha. ${ }^{149}$ This personal interest in the case by the plaintiffs, when they were not there to testify but rather only to attend depositions, ${ }^{150}$ suggests that their interests in the case are clearly beyond the financial, as it costs time away from work and extra money to attend such an event. Clearly, a financial settlement for these individuals would not fully meet their interests.

This motivation to expose misdeeds was also motivating Matt Lee, mentioned in Part I, who, even after settling his case, remained unsatisfied

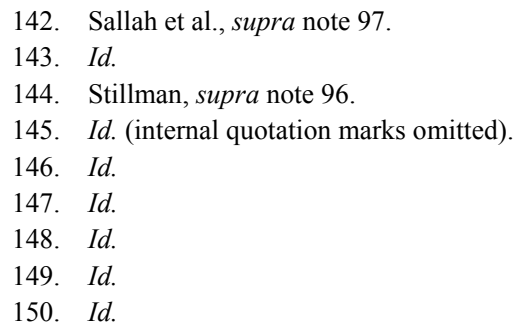


with the resolution. ${ }^{151}$ After the case, in February of 2014, "Lee wrote an angry opinion piece about his experiences for the Silver Pinyon Journal, an online news service in Humboldt County."

'I intend to throw a spotlight on this little operation they've got going on in Humboldt County, Nevada,' he wrote. 'I intend to make it as difficult as possible for them to continue with their modus operandi. If they are going to violate civil rights, I'm going to make sure people hear about it. 153

These interests in making people pay or to expose their rough treatment make a standard settlement of a civil dispute, i.e. monetary compensation, unlikely. Because the primary interests here are more closely tied to respect and voice in the process, a settlement that gives the claimant some or all of their money is unlikely to satisfy them entirely.

\section{The Zero-Sum Nature of the Dispute}

One particular issue with cash forfeiture is the zero-sum nature of the dispute. Zero-sum disputes are ones in which there are no tradeoffs among multiple issues, as the parties are disputing over a single asset. ${ }^{154}$ In the case of cash forfeiture, the parties are negotiating over a single asset-i.e. the amount of cash-where it is true that a dollar in the government's pocket is a dollar that is not in the original owner's pocket and vice versa. It is not possible to share currency or divide ownership in some other way, as may be possible with, say, real property, in which ownership can be divided over time or rental value can be split among many people. The indivisible nature of the forfeited cash in dispute can lead to a "zero-sum mindset" or "fixed pie" thinking, which creates a serious stumbling block in negotiation. ${ }^{155}$ This view of the dispute can hamper negotiations or cause them to break down entirely because the mindset that a gain for the other party is seen as a loss for me makes any mutually beneficial trades a psychological impossibility. ${ }^{156}$

\footnotetext{
151. O'Harrow Jr. et al., They Fought the Law, supra note 15.

152. Id.

153. Id.

154. H. Peyton Young, Dividing the Indivisible, 38 AM. BEHAV. SCIENTIST 904, 904-05 (1995).

155. Id.

156. Lee Ross, Reactive Devaluation in Negotiation and Conflict Resolution, in BARRIERS TO CONFLiCt ReSOLUTION 26, 28 (Kenneth J. Arrow et al. eds., 1995).
} 


\section{Lack of Pre-Trial Resolution Procedures}

The particular laws around cash forfeiture exacerbate the zero-sum nature of civil cash forfeiture disputes. These lack of pre-trial resolution procedures both discourage early settlement of cases and puts the imperative on judges to resolve these disputes. ${ }^{157}$

\section{Lack of Hardship Release as a Form of Pre-Trial Resolution}

For most types of civil asset forfeiture, the property owner may seek what is known as "hardship release" to secure pretrial return of seized property. ${ }^{158}$ In order to reduce the burden of civil forfeiture, CAFRA "entitles claimants to 'immediate release of seized property' pending the outcome of trial[,]" as long as the claimant meets five criteria that balance the risk of destruction of the property with the hardship to the claimant. ${ }^{159}$ It would seem that hardship release might give judges a way to resolve a dispute before trial by creating a mechanism for at least releasing some or all of the seized assets. However, paragraph (8) in the same section as hardship release specifically exempts currency from hardship release, unless those cash assets are the entire assets of a legitimate business. ${ }^{160}$ Hardship release, which would seem to be a pre-trial resolution mechanism, is unavailable to judges in this instance. ${ }^{161}$

\section{Lack of Other Forms of Pre-Trial Resolution}

Other forms of pre-trial resolution are also unavailable for cash civil forfeiture disputes. Another strategy for pre-trial release of property is through the claimant submitting a petition for remission or mitigation. ${ }^{162}$ "Remission refers to the complete release of the seized property, [whereas] mitigation refers to . . . returning some, but not all, of the property."163 While seizing agencies each have regulations to govern civil forfeiture

\footnotetext{
157. See infra Part IV.

157. Ford, supra note 36, at $465-66$.

159. Id. at $465 ; 18$ U.S.C. $\S 983(\mathrm{f})(1)(\mathrm{A})-(\mathrm{E})(2012)$.

160. 18 U.S.C. $\S 983(f)(8)(A)$. Ford, supra note 36, at 465-66, n.89 (citing Kaloti Wholesale, Inc. v. United States, 525 F. Supp. 2d 1067, 1070 (E.D. Wis. 2007)).

161. See Christopher Ingraham, Since 2007, the DEA has Taken \$3.2 Billion in Cash from People not Charged with a Crime, WAsh. POsT: WonkBlog (Mar. 29, 2017), https://www.washingtonpost.com/news/wonk/wp/2017/03/29/since-2007-the-dea-has-taken-3-2billion-in-cash-from-people-not-charged-with-a-crime/.

162. Ford, supra note 36 , at 463.

163. Id. (citing Dee R. Edgeworth, Asset Forfeiture: Practice and Procedure in State AND FEDERAL COURTS 72 (3rd ed. 2014)).
} 
proceedings, ${ }^{164}$ and these mechanisms are "intended to alleviate some of the harshness of seizure and forfeiture[,] ${ }^{165}$ both options fail to" provide an adequate pre-trial resolution to a civil forfeiture cash dispute. As others have noted, the remission and mitigation process is subject to the almost complete discretion of the seizing agency (including the discretion to deny all relief), the seizing agency is not required to provide a hearing, and judicial review of these administrative proceedings are extremely limited. ${ }^{166}$ Similarly, motions to challenge unlawful seizures under Federal Rule of Criminal Procedure $41(\mathrm{~g})^{167}$ are extremely time limited and are only granted before the forfeiture action by the government commences, ${ }^{168}$ making it unavailable as a pre-trial resolution mechanism. This lack of pre-trial dispute resolution mechanisms limits the ability of judges to resolve disputes and limit the parties' opportunity for interactions leading to settlement.

\section{E. Endowment Effects and Other Psychological Phenomena}

A number of psychological barriers to settlement exist in the civil cash forfeiture context that also makes settlement of these cases unlikely. While barriers to settlement exist in all civil disputes, ${ }^{169}$ a few seem particularly salient in this context.

First is the role of endowment effects. ${ }^{170}$ The endowment effect, at its core, is that "[a] thing possessed becomes more valuable to the holder than to the market." 171 In general, disputants are less sensitive to their current entitlements and more sensitive to their change relative entitlements. ${ }^{172}$ In the case of civil forfeiture, it is difficult to achieve settlement if one or the other disputant is in the grip of this particular effect. In particular, it is likely that once the government has seized the property, they are likely to

164. EDGEWORTH, supra note 163 , at 72 .

165. Ford, supra note 36 , at 463 . Ford also notes that given the overlapping deadlines for filing remission and mitigation versus filing for filing claims opposing forfeiture, claimants need to file both a claim opposing forfeiture at the same time as they file for remission or mitigation, lest they lose their remission or mitigation claim and also miss the deadline for filing an opposition. Id. at 462 .

166. Id. at 464 .

167. See FED. R. CRIM. P. 41(g).

168. Ford, supra note 36 , at 465 .

169. See Robert H. Mnookin \& Lee Ross, Introduction, in BARRIERS TO CONFLICT RESOLUTION 2, 3-5. (Kenneth J. Arrow et al. eds., 1995).

170. See Daniel Kahneman et al., Anomalies: The Endowment Effect, Loss Aversion, and Status Quo Bias, 5 J. ECON. PERSP. 193, 194 (1991).

171. Richard Birke, Neuroscience and Settlement: An Examination of Scientific Innovations and Practical Applications, 25 OHIO ST. J. ON DISP. RESOL. 477, 495 (2010).

172. Id. at $519-20$. 
overvalue it because it is in their possession, and are less likely to settle the dispute because of their feeling of relative entitlement to the proceeds.

Closely related to this is the concept of loss aversion, ${ }^{173}$ meaning "[p] eople are risk seeking in the face of losses." "I74 If a scenario is framed as a potential loss, people are more likely to spend extra time and energy in avoiding this loss than they would in the case of a similar gain. ${ }^{175}$ In the case of civil forfeiture, if lawyers for the government perceive any settlement as a "loss" that they are incurring, relative to the entitlement they feel to the cash already seized, they will be more "risk seeking" in taking a chance at a civil forfeiture judgment against them (or an innocent owner defense succeeding) than being inclined to settle the dispute. The nature of civil forfeiture disputes, in which the laws are structured such that any unopposed claim by the government automatically is forfeited, plays in to this entitlement perspective. Similarly, if claimants to property perceive the forfeiture against them as a loss, they too will be more risk seeking in trying to regain what they see as their lost property. They will be more likely to take the risk of litigating for a potential win in challenging a civil forfeiture action or raising an innocent owner defense, where they might ordinarily settle or walk away in the face of another type of loss.

A final psychological phenomenon that plays in to the settlement of forfeiture disputes is the concept of fairness as a decision-making criterion, ${ }^{176}$ where people are likely to "reject deals that leave them better off than no deal if they perceive that their norms of fairness are being violated in accepting the deal."177 This may be particularly salient for defendants in this context, who may be particularly aggrieved at their rough treatment at the hands of law enforcement and are willing to reject any deal that is offered as a settlement even if is better than no agreement and the risk of going to hearing. As expressed above, ${ }^{178}$ many potential claimants feel aggrieved at the process of civil forfeiture and therefore are unlikely to settle, particularly for a mere monetary settlement.

173. Id. at 497 (citing Richard Birke \& Craig R. Fox, Psychological Principles in Negotiating Civil Settlements, 4 Harv. NegOt. L. Rev. 1, 43 (1999)).

174. Birke, supra note 171, at 497 (citing Birke \& Fox, supra note 173, at 43).

175. Daniel Bernoulli, Exposition of a New Theory on the Measurement of Risk, 22 ECONOMETRICA 23, 24 (Louise Sommer trans., 1954).

176. Birke, supra note 171 , at 496.

177. Id. (citing Werner Güth et al., An Experimental Analysis of Ultimatum Bargaining, 3 J. ECON. BEHAV. \& ORG. 367, 383-84 (1982); Birke \& Fox, supra note 173, at 34-35).

178. See supra Section III.B. 


\section{THE Role of the MANAGERIAL JUdGe IN CIVIL Forfeiture DISPUTES}

Even if it is true, as claimed above, that civil forfeiture cases are unlikely to settle due to the structural and psychological barriers affecting these types of disputes, it may seem outside the traditional judicial role for judges to influence on this state of affairs. Under the "traditional judicial role," judges are the more passive actors, with the parties and their counsel taking the active role in framing disputes, and the judge then using legal standards to resolve those disputes. ${ }^{179}$ Under this conception of judging, judges are not meant to influence the settlement or lack thereof of any particular case, as this would allow too much control over the process and potentially lead to coerced settlements. ${ }^{180}$

However, this traditional role conception is increasingly outdated, as can be seen by looking at the judicial settlement conference, a now common practice in the civil context. In the judicial settlement conference, judges take a "managerial," rather than passive, role towards their docket, and meet with counsel and the parties to settle cases before they come to trial. ${ }^{181}$ Under the managerial conception of judges, the management of the case docket and the efficient resolution of cases is more important than the trial of any individual case. ${ }^{182}$ The managerial "judge can have a positive impact on the outcome of a dispute by becoming more, rather than less, involved."

While this may be appropriate for the civil context, as noted above, a civil forfeiture dispute can be seen as a hybrid between a civil and criminal case. However, the model of the managerial judge has also been adopted in the criminal context. ${ }^{184}$ The plea bargain, traditionally a private resolution between the prosecution and defense counsel and their client in criminal cases, has seen increased judicial participation become the

179. Jeffrey A. Parness, Improving Judicial Settlement Conferences, 39 U.C. DAVIS L. REV. 1891, 1893-94 (2006) (citing Jonathan T. Molot, An Old Judicial Role for a New Litigation Era, 113 YALE L.J. 27, 29 (2003); Judith Resnik, Managerial Judges, 96 HARV. L. REV. 376, 445 (1982)).

180. Id

181. See Resnik, supra note 179, at 376-77; see also Rishi Raj Batra, Judicial Participation in Plea Bargaining: A Dispute Resolution Perspective, 76 OHIO ST. L.J. 565, 571-72 (2015).

182. Batra, supra note 181, at 572 (citing Resnik, supra note 179, at 376-77, 379; Marc Galanter, “. . . A Settlement Judge, Not a Trial Judge:” Judicial Mediation in the United States, 12 J. L. \& Soc’Y $1,3(1985))$.

183. Batra, supra note 181, at 572 (citing Galanter, supra note 182, at 3)).

184. See generally Nancy J. King \& Ronald F. Wright, The Invisible Revolution in Plea Bargaining: Managerial Judging and Judicial Participation in Negotiations, 95 TEX. L. REv. 325 (2016) (finding highly structured docket management by judges in criminal cases in a comprehensive study of judicial participation in plea bargaining). 
norm. ${ }^{185}$ As the judicial role conception for judges in both the civil and criminal contexts shifts to a managerial role, judges can also play an appropriate role in the in the resolution of civil forfeiture disputes. ${ }^{186}$

Given this modern managerial role for judges handling disputes, including civil forfeiture disputes, judges operating in the managerial role can and indeed should take actions that allow them to manage their docket appropriately, and one aspect of this management is, of course, to encourage the settlement of cases. The next Part of this Article discusses some actions that a judge, who is looking to help settle civil forfeiture cases, can take to overcome the barriers already identified. ${ }^{187}$

\section{OVERCOMING BARRIERS TO SETTLEMENT IN CIVIL Forfeiture DISPUTES}

Certainly, one way to make things easier for innocent property owners who may be impacted by civil forfeiture is to abolish the practice altogether, and certainly, some have called for this exact result. ${ }^{188}$ However, it is important to remember that civil forfeiture does have several advantages ${ }^{189}$ and that we are unlikely to see legislative change soon. At the moment, only New Mexico, Nebraska, and the District of Columbia have banned the use of civil forfeiture absent a criminal conviction. ${ }^{190}$ Until legislative change is available, judicial settlement can encourage resolution of these cases.

\section{A. Using Settlement Conferences to Encourage Procedural Justice}

One of the best tools that judges can use in the encouragement of settlement in these cases is to embrace the idea of finding procedural, rather than distributive, justice in these cases. While distributive justice "focuses on perceptions of and criteria to determine the substantive

\footnotetext{
185. Id. at 392 .

186. See generally Batra, supra note 181, at 572-79 (providing a fifty-state survey of judicial participation in plea bargaining and making normative recommendations for how judges should appropriately conduct the process in this role).

187. See supra Part III.

188. CARPENTER II ET AL., supra note 3, at 7.

189. See supra Part II.

190. CARPENTER II ET AL., supra note 3, at 6 (noting reforms to eliminate civil forfeiture in the District of Columbia and New Mexico); Nick Sibilla, Nebraska Just Abolished Civil Forfeiture, Now Requires a Criminal Conviction to Take Property, ForBES (Apr. 20, 2016, 10:44 AM), https://www.forbes.com/sites/instituteforjustice/2016/04/20/nebraska-just-abolished-civil-forfeiturenow-requires-a-criminal-conviction-to-take-property/\#27a910401e5f (discussing Nebraska's elimination of civil forfeiture).
} 
fairness of . . outcomes[,]"191 "[p]rocedural justice is concerned with the fairness of the procedures or processes that are used to arrive at outcomes." 192

Procedural justice is evaluated by disputants focusing on four attributes of the process. ${ }^{193}$ First is whether the process allowed them to tell their side of the story, known as "voice." 194 The second is whether the authority considered their story in an unbiased and principled way, known as "neutrality." 195 Third is whether the authorities were seen as caring about the process ("trustworthiness"). ${ }^{196}$ Fourth is whether the disputant was treated with dignity, also known as "respect." 197 A "lack of procedural justice can lead to a significant sense of unfairness" in disputant's minds, ${ }^{198}$ which can lead to a negative attitude about and a dissatisfaction with the justice system, ${ }^{199}$ and can also erode the feeling of "obligation to obey the law." 200

This is particularly salient in the context of civil forfeiture, in which claimants, in particular, feel roughly treated, ${ }^{201}$ and would seem to lack the indicia of voice, trustworthiness, and even handed treatment. As research has shown, however, adding a third party neutral to the dispute can help with all of these indicia of procedural fairness. ${ }^{202}$ Having claimants participate in a judicial settlement conference, ${ }^{203}$ in which the judge plays the role of a third party neutral, ${ }^{204}$ can allow claimants to voice their concerns, have them heard, and even interact with the judge in a way that

191. Nancy A. Welsh, Making Deals in Court-Connected Mediation: What's Justice Got to Do With It?, 79 WASH. U. L. Q. 787, 817 (2001).

192. Id. (emphasis added).

193. Tom R. Tyler \& Hulda Thorisdottir, A Psychological Perspective on Compensation for Harm: Examining the September 11th Victim Compensation Fund, 53 Depaul L. ReV. 355, 380 (2003); see also Michael M. O'Hear, Plea Bargaining and Procedural Justice, 42 GA. L. REV. 407, 410-11 (2008).

194. Tyler \& Thorisdottir, supra note 193 , at 380-81.

195. Id.

196. Id.

197. Id.

198. Batra, supra note 181, at 570 (citing O'Hear, supra note 193, at 424).

199. Tom R. Tyler, Citizen Discontent with Legal Procedures: A Social Science Perspective on Civil Procedure Reform, 45 AM. J. CoMP. L. 871, 875 (1997).

200. O'Hear, supra note 193, at 422; see also Welsh, supra note 191, at 817-18.

201. See supra Section III.B.

202. Welsh, supra note 191, at 816.

203. See Carrie Menkel-Meadow, For and Against Settlement: Uses and Abuses of the Mandatory Settlement Conference, 33 UCLA L. REV. 485, 506-07 (1985).

204. See id. 
helps them understand the procedure of civil forfeiture, ${ }^{205}$ regardless of the outcome.

\section{B. Creating Post-Seizure, Pre-Detention Procedure}

While ultimately the legislature at the federal or state level can help increase the amount of process for claimants in civil forfeiture hearings, the courts can, on their own, create procedure for checking the pretrial forfeiture of cash.

The Second Circuit, in Krimstock v. Kelly (Krimstock V), ${ }^{206}$ created such a process for civil forfeiture. In a case regarding the seizure of a vehicle associated with a violation of a driving-while-intoxicated statute, the court held "that, at a minimum, [a] hearing must enable claimants to test the probable validity of continued deprivation of [the property]."207 The Seventh Circuit has also required a post-seizure hearing for continued deprivation of vehicles and cash. ${ }^{208}$ As one scholar has noted, these postseizure hearings in the context of cash forfeiture may even be required by due process considerations. ${ }^{209}$

Such a post-seizure hearing of civil forfeiture cases could take many forms. However, the process does not have to be demanding. One proposed model suggests that this "Krimstock hearing" would "provide[] an adversarial process in which the claimant can contest that probable cause exists on three grounds: (1) whether probable cause existed for the offense underlying the forfeiture, (2) whether the government is likely to prevail in a forfeiture action, and (3) whether the government needs to detain the cash pending the forfeiture action." ${ }^{210}$ This would remain a small burden on the government "[b]ecause law enforcement must already demonstrate probable cause to seize property." 211

Even a small amount of pre-detention procedure consistent with due process would overcome some of the barriers to settlement considered above. In particular, by creating this procedure, judges help break some

\footnotetext{
205. See Ronald T.Y. Moon, Visions of a New Legal System: Could There Be a Legal System that Better Incorporates the Strengths of ADR and Existing Legal Institutions?, 15 REV. LITIG. 475, 480 (1996).

206. Krimstock v. Kelly (Krimstock V), 306 F. 3d 40, 69 (2d Cir. 2002).

207. Id. at 69-70.

208. Ford, supra note 36, at 469 (citing Smith v. City of Chicago, 524 F.3d 834 (7th Cir. 2008), vacated as moot sub. nom Alvarez v. Smith, 558 U.S. 87 (2009)).

209. Ford, supra note 36, at 469.

210. Id. at 479 (citing Third Amended Order and Judgment, Krimstock v. Kelly (Krimstock IV), 506 F. Supp. 2d 249 (S.D.N.Y. 2007) (No. 99 Civ. 12041 (HB)), 2007 U.S. Dist. LEXIS 82612, at *2).

211. Ford, supra note 36, at 479 .
} 
of the psychological barriers to settlement that may be held by either party. The government may not see settlement as a loss since the procedure provided either signals that their entitlement is not as strong as assumed and comes with even higher risk which may overcome some of the loss aversion that they are likely to feel. In addition, the defendants are likely to feel that they have some access to equity and justice seeking, to have some sort of procedure granted to them, even without prevailing. Most importantly, this reduces the lack of pre-trial resolution procedures so that parties are forced to come together and interact in a forum that is accessible for the claimant.

\section{Encouraging Creative Settlements}

One significant advantage that a judge serving as a neutral or adding a mediator to the dispute can do is encourage the development of creative solutions to the dispute. As noted above, the supposed zero-sum nature of the dispute, in which the government and the claimant are only bargaining over the amount of money to be returned to the claimant, can lead to a zero-sum mindset where parties cannot overcome impasse. ${ }^{212}$ If the parties' interests are only seen as monetary, these cases are unlikely to resolve, even with an active judicial participant as a mediator.

One particular creative option that could be considered is an apology for rough treatment on behalf of the government or law enforcement officers. The power of apology has been studied extensively in other contexts and has been found to increase party satisfaction and encourage settlement. For example, in cases of medical malpractice, an apology to the patient by the doctor reduced or even eliminated the demand for a cash award by the patient or the patient's family. ${ }^{213}$ This is also consistent with our understanding of procedural justice. As noted above, a lack of respect is associated with a lowered perception of procedural justice, ${ }^{214}$ and clearly, rough treatment at the hands of law enforcement that has been reported in these cases ${ }^{215}$ is perceived as a lack of respect. Of course, an apology may not be the sole remedy that a claimant receives, but it is possible that a reduced award that meets the government interest can be accomplished with the use of an apology.

\footnotetext{
212. See supra Part III.

213. See generally Benjamin Ho \& Elaine Liu, Does Sorry Work? The Impact of Apology Laws on Medical Malpractice, 43 J. RISK \& UNCERTAINTY 141 (2011) (discussing the impact of apologies in the medical malpractice setting).

214. O'Hear, supra note 193, at 426.

215. See Sallah et al., supra note 97.
} 


\section{CONCLUSION}

Civil forfeiture proceedings against pure cash holdings associated with suspected criminal activities are a particularly difficult type of case for resolution. Structural and psychological barriers prevent parties from resolving these cases outside of a trial. Without judicial intervention, these cases are unlikely to resolve. As the number and amount of assets seized in civil forfeiture increases, we are likely to see an increase the number of these cases, given the incentives of both the government and defendants to take these cases to trial.

This increase in cases will lead to increased docket congestion without proper control by judges, which is at odds with the modern managerial style of judging. In order to manage their dockets appropriately, judges should implement particular reforms to increase the likelihood of settlement of these types of disputes. In particular, judges should try to use judicial settlement conferences, additional pretrial procedures, and creative options to overcome these barriers to settlement.

These reforms will not solve the larger issues involved in civil forfeiture, including individuals who have assets seized which were not involved in criminal activity. However, these small reforms can help encourage settlement of these disputes, which will reduce docket congestion and allow for partial recovery of assets. Hopefully, other reforms by legislators, such as reducing the incentives for forfeiture, will address the larger ills of the civil forfeiture system. 